\title{
Cadmium and Lead Toxicity, Modulating Roles of Age and Trace Metals on Wistar Rat Cortical Cells
}

\author{
Olugbenga A. Ayannuga ${ }^{1}$, John A. Oyekunle ${ }^{2}$, Omamuyovwi M. Ijomone ${ }^{3} \&$ Blessing I. Ibeachusim ${ }^{2}$ \\ ${ }^{1}$ Department of Anatomy and Cell Biology, College of Medicine, Obafemi Awolowo University, Ile-Ife, Nigeria \\ ${ }^{2}$ Department of Chemistry, Obafemi Awolowo University, Ile-Ife, Nigeria \\ ${ }^{3}$ Department of Human Anatomy, Cross River University of Technology, Okuku Campus, Nigeria \\ Correspondence: Olugbenga A. Ayannuga, Department of Anatomy and Cell Biology, College of Medicine, \\ Obafemi Awolowo University, Ile-Ife, Nigeria. Tel: 234-80-8071-0899. E-mail: olugbengayannuga@gmail.com
}

Received: February 26, 2015 Accepted: March 11, 2015 Online Published: June 28, 2015

doi:10.5539/ep.v4n3p51 URL: http://dx.doi.org/10.5539/ep.v4n3p51

\begin{abstract}
The role of age and concomitant exposure to trace elements on Wistar rats was investigated in this study. Fifteen 12 weeks old rats divided into groups A, B and C, and fifteen 36 weeks old rats divided into groups D, E and F were acclimatised for 2 weeks. Groups A and D served as the control groups and were administered distilled water. Groups B and $\mathrm{E}$ were administered $1 \mathrm{~mL}$ each of $5 \mathrm{ppm}$, while groups $\mathrm{C}$ and $\mathrm{F}$ were administered $1 \mathrm{~mL}$ each of 10 ppm of lead, cadmium, copper and zinc solutions daily for 1 week. Rats were sacrificed by cervical dislocation and the harvested cerebrum was digested in $\mathrm{HNO}_{3}$ and $\mathrm{HClO}_{4}$. Quantification of metals was done using Flame Atomic Absorption Spectrophotometer. A $5 \mu \mathrm{m}$ thick paraffin section of the cerebrum obtained at the level of the optic chiasma was stained with H\&E and evaluated.

Zinc concentration was markedly reduced while cadmium and lead concentrations were increased in both experimental groups across the age groups in a dose-dependent fashion. Copper concentration was reduced in rats with $5 \mathrm{ppm}$ exposure while in those with $10 \mathrm{ppm}$ exposure it was similar to the control. Pyknotic glial cells were more and widespread in the younger rats but few and restricted to the mid-cortical region in older rats. Early neuronal necrosis was widespread in older rat group but restricted to internal granular layer in young rats. Central neuronal chromatolysis was noted in both groups of younger rats but restricted to the $5 \mathrm{ppm}$ group of older rat group.

Cerebral concentration of zinc was reduced in cadmium and lead exposure. Glial cells pyknosis were widespread in older rats, but early neuronal necrosis was more widespread in younger rats, showing that the cellular effect of heavy metal is age dependent.
\end{abstract}

Keywords: cadmium, cerebrum, copper, lead, morphological changes, rats, zinc

\section{Introduction}

Some of the oldest cases of heavy metal induced health problems in the world, starting from ancient civilizations, were caused by both natural and anthropogenic activities such as mining, smelting, combustion of coal and mineral oils, alloy processing and paint making (Alloway and Jackson, 1991; Cunningham,1995). In the recent years, improvements in food production and processing technology had increased the chances of contamination of food with various environmental pollutants, especially heavy metals. Virtually all aspects of animal and human immune system are compromised whenever high levels of heavy metals gain access, through food chain or other means, into the system (Nordberg et al., 1985).

At elevated levels, essential as well as non-essential elements are known to cause morphological abnormalities, reduced growth, impairment and dysfunction of the cardiovascular, endocrine, gastro-intestinal, immune, central and peripheral nervous systems. Such elevation also increase allergic reactions, cause genetic mutation, compete with essential trace metals for biochemical bond sites thereby disrupting the trace elements metabolism (Pier 1975; Baykov et al., 1996; Garry, 2001; Lo'pez-Alonso et al., 2002).

The study of distribution and localization of heavy metals in the tissues of some animals showed that the most affected organs were livers, kidneys, the adrenal gland, lungs, hair and skin, and small intestines (Horky et al., 
2002; Jurczuk et al., 2005). In some cases they may also lead to mental disorders and loss of brain function (Suresh et al., 1994).

Ordinarily, Cadmium (Cd) is a relatively rare element usually present in environmental media at low concentrations (Alloway \& Jackson, 1991).However, it is finding increasing applications in electroplating, colour pigments for paints and plastics, and as a cathode material for nickel-cadmium batteries. Hence, its levels in environmental matrices are increasing (Bulat et al., 2009).

Food is one of the principal environmental sources of cadmium (Baykov et al., 1996). For those who do not smoke or who are not occupationally exposed, the diet remains the primary source of Cd exposure (Louekari et al., 1989). As cadmium moves through the food chain it becomes more and more concentrated as it reaches the carnivores where it increases in concentration by a factor of approximately, 50 to 60 times (Bernard, 2004). Cadmium is classed as a cumulative toxin, implying that the concentration of $\mathrm{Cd}$ in target organs will increase with time (Bernard, 2004). Cadmium affects various organs such as bones, kidney and nervous system. The effects of $\mathrm{Cd}$ in man include kidney damage (Triger et al., 1989), pains in the bones (Kjellstrom, 1992) and endocrine disruption (Schantz \& Widholm, 2001). Lead and cadmium are the two most abundant toxic metals in the environment (Nriagu et al., 1987; Suresh et al., 1993). Extrinsic factors, such as the trace element compositions of the diet have been shown to decrease the effects of Cd toxicity (Fox, 1979).

The quantity of lead $(\mathrm{Pb})$ used in the present decade far exceeds the total amount consumed in all previous eras (Phillips et al., 2003). Lead is a metabolic poison and a neurotoxin that binds to essential enzymes and several other cellular components and inactivates them (Cunningham, 1995). Toxic effects of $\mathrm{Pb}$ are seen on haemopoietic, nervous, gastrointestinal and renal systems (Baykov et al., 1996). The ubiquity of $\mathrm{Pb}$ and its toxicity even at low concentrations make it one of the most insidious of all environmental hazards. It has been argued that, for humans, there is no level below which exposure is harmless (Goyer, 1996). The major risk of $\mathrm{Pb}$ as an environmental contaminant is its toxicity to the nervous system. The most susceptible populations are children, particularly toddlers, infants in the neonatal period, and the foetus. Special attention is often given to exposure in children, because it may result in developmental problems (Suresh et al., 1994). The principal route of exposure for people in the general population is food. Other sources that produce excess exposure and toxic effects are lead-based indoor paint in old dwellings, lead in dust from environmental sources, contaminated drinking water, air from combustion of leaded fossil fuels and lead-containing industrial emissions, hand-to-mouth activities of young children living in polluted environments, lead-glazed pottery and, less commonly, lead dust brought home by industrial workers on their shoes and clothes (Orisakwe, 2014).

On human beings, $\mathrm{Pb}$ has physiological and neurological effects (Fullmer, 1992). While acute effects of $\mathrm{Pb}$ poisoning are manifested in symptoms such as nausea, vomiting, abdominal pains, anorexia, constipation, insomnia, anaemia, irritability, mood disturbance and coordination loss, more chronic toxicity results in restlessness, hyperactivity, confusion, memory impairment, convulsions, coma and death (Grandjean \& Nielson, 1979). On the foetus and children, the chronic effects of $\mathrm{Pb}$ may include behavioural changes and impaired performance in IQ tests (Needleman, 1987; Ogunfowokan et al., 2002). Blood Pb concentrations of up to $10 \mu \mathrm{g} / \mathrm{dL}$ in children and adolescents can cause cognitive deficits (Lanphear et al., 2002; Wu et al., 2003).

Assimilation of essential metals such as $\mathrm{Cu}$ and $\mathrm{Zn}$ in living systems varies widely according to a combination of factors. One of such factors is the ability of certain toxic metals to disrupt the absorption and assimilation of essential metals in various organs or tissues of living things. Some metals, such as $\mathrm{Zn}$ or $\mathrm{Cu}$, are constituents of enzymes that are indispensable for the proper functioning of metabolic processes. When such metals are displaced by potentially toxic ones, they lose their biochemical functions which may be shown in abnormal development of organs and tissues of living systems. This study was carried out to determine the extent to which $\mathrm{Cd}$ and $\mathrm{Pb}$ ingestion could inhibit the uptake, storage and utilization of $\mathrm{Cu}$ and $\mathrm{Zn}$ in the brain tissues of rats of varying ages and possible effect of such ingestion on the cellular constituents of the cerebral cortex.

\section{Materials and Methods}

\subsection{Experimental Animals}

Fifteen 12 weeks old rats weighing between $100 \mathrm{~g}$ and $120 \mathrm{~g}$, and fifteen 36 weeks old rats weighing between $200 \mathrm{~g}$ and $245 \mathrm{~g}$ were used for this study. Rats were obtained from the central animal house of the College of Health Sciences, Obafemi Awolowo University, Ile-Ife, Nigeria. They were acclimatised for a period of 2 weeks after which they were divided into 6 groups of 5 rats each. The younger rats were divided into groups A, B and C, while the older rats were divided into groups D, E and F. Rats were kept in plastic cages and housed in well aerated animal holding of the Department of Anatomy and Cell Biology, Obafemi Awolowo University, Ile-Ife. Pelletized rat chow and water were provided for the rats ad libitum and normal light and dark cycle was maintained 
throughout the study.

\subsection{Purification of Reagents and Apparatus}

All standard laboratory glassware (flasks, beakers and measuring cylinders) were scrubbed with a nylon brush in a hot detergent solution, rinsed with hot tap water until no more soap was observed. They were then rinsed with cold tap water and finally with distilled water and drained dry. The polythene sample bottles were also soaked in $0.1 \mathrm{M}$ $\mathrm{HNO}_{3}$ for 48 hours followed by thorough rinsing with distilled water. All cleaned glassware was stored prior to use under clean polyethylene foil to prevent contamination by fallout from laboratory air. All the chemicals and reagents used in this study were of analytical reagent grade, as specified by the Committee on Analytical Reagents of the American Chemical Society. They included Nitric acid, $\mathrm{HNO}_{3}$ (Rieldel-de Haën, Germany) and Perchloric acid, $\mathrm{HClO}_{4}$ (Rieldel-de Haën, Germany).

\subsection{Heavy Metal Preparation and Administration}

Cadmium, lead, copper and zinc salts were dissolved in distilled water under sterile conditions to a concentration of $5 \mathrm{ppm}$ and $10 \mathrm{ppm}$ each. Groups A and D served as the control groups and were administered distilled water, groups $\mathrm{B}$ and $\mathrm{E}$ were administered $1 \mathrm{ml}$ of each $5 \mathrm{ppm}$ heavy metal solution daily for 1 week while groups $\mathrm{C}$ and $\mathrm{F}$ were administered $1 \mathrm{ml}$ of each $10 \mathrm{ppm}$ heavy metal solution for the same period. Administration of the heavy metal solutions and distilled water was done with the use of oral cannula.

\subsection{Sample Collection and Preparation}

At the completion of the experiment, rats in each group were sacrificed by cervical dislocation. Rats were decapitated and the brain harvested on ice. Part of the cerebrum were kept in pre-treated petri dishes and stored in the deep freezer at $4^{\circ} \mathrm{C}$ prior to chemical analysis. The other parts of the cerebrum were immersion fixed in $10 \%$ formal saline prior to histological processing.

\subsection{Digestion of Rat Brain Tissues}

Between 0.2 and $0.5 \mathrm{~g}$ each of the frozen brain tissue was accurately weighed and digested using $\mathrm{HNO}_{3}$ and $\mathrm{HClO}_{4}$ in a Teflon beaker under the fume cupboard. Sample was heated with $5 \mathrm{~mL}$ concentrated $\mathrm{HNO}_{3}$ in the fume cupboard at a temperature of about $120-150^{\circ} \mathrm{C}$ using a thermostated hot plate. Replenishment was done from time to time as necessary with about $1 \mathrm{~mL}$ of concentrated $\mathrm{HNO}_{3}$ to avoid evaporation to dryness. This was done until a clear faint yellow solution was obtained. After cooling, about $2 \mathrm{~mL} \mathrm{HClO}_{4}$ was added and further digestion was done for about 30 minutes. This step ensured the complete digestion of the sample, released any metal complexing with $\mathrm{HNO}_{3}$ and made all metals existed in their highest oxidation states. The content of the Teflon beaker was quantitatively turned into a $25 \mathrm{~mL}$ volumetric flask and the volume was made up to $25 \mathrm{~mL}$ with doubly distilled water and then transferred into the sample bottle in readiness for Atomic Absorption Spectrophotometric (AAS) analysis.

\subsection{Determination of Heavy Metals in the Samples}

The resulting solutions were analyzed for their heavy metal concentrations using Flame Atomic Absorption Spectrophotometry (FAAS) Buck Scientific 205 model at the International Institute of Tropical Agriculture (IITA) Ibadan, Nigeria.

\subsection{Quality Control Work}

\subsubsection{Blank Determination}

The blank determination was carried out to ascertain the background levels of the analytes of interest in the materials and reagents used for analysis. This was done by running a separate determination under the same experimental conditions employed in the actual analysis of the sample, but excluding the sample. The values obtained from running blank determinations were subtracted from the analyte values as applicable. The blank values fell between 0.0001 and $0.0002 \mu \mathrm{g} / \mathrm{mL}$.

\subsubsection{Calibration of Instrument}

Although FAAS offers potential advantages such as simplicity, ruggedness, low cost and ease of miniaturization, its calibration was necessary to evaluate the response of the analytical procedure with respect to known quantities of the standards of the heavy metals of interest so that the response to unknown quantities in the samples could be reliably estimated. For the FAAS, 25, 20, 15, 12, 10, 7, 5, 2 and $1 \mu \mathrm{g} / \mathrm{mL}$ concentrations of each metal solution were freshly prepared by serial dilution for the determination of metals in tissues samples (Table 1). These solutions were run on the FAAS to obtain the working calibration graph which was used to estimate the levels of heavy metals in the samples by automatic interpolation with respect to the calibration graph. 


\subsubsection{Recovery Experiment}

Two $0.5 \mathrm{~g}$ portions of the brain tissue were used for recovery analysis. One portion was spiked with $10 \mathrm{~mL}$ of 1000 $\mathrm{mg} / \mathrm{L}$ standard mixture of the heavy metal solutions while the other (control) portion was left unspiked. The two portions were separately but similarly taken through the procedures outlined earlier for tissue digestion. The resulting solutions were subjected to FAAS analysis. The percentage recoveries $(\% \mathrm{R})$ of heavy metals were determined by comparing the concentration values of each metal from the spiked and the unspiked sample results using the relationship:

$$
\% \mathrm{R}=\frac{\mathrm{A}-\mathrm{A}^{\prime}}{B} \times 100 \%
$$

where $\mathrm{A}=$ heavy metal concentration in the spiked tissue sample, $\mathrm{A}^{\prime}=$ heavy metal concentration in the unspiked tissue sample, and $\mathrm{B}=$ the amount of heavy metal used for spiking.

\subsection{Histological Processing and Staining}

Brain slices of the cerebral cortex were obtained at the level of the optic chiasma from the fixed cerebrum. Slices were passed through ascending concentration of alcohol for dehydration following which it was cleared, paraffin infiltrated and embedded. From each cerebral tissue across the groups, $5 \mu \mathrm{m}$ thick paraffin section was obtained. Sections were stained with Heamatoxylin and Eosin for cortical architecture and cellular composition studies.

\section{Results}

\subsection{Calibration of FAAS and Percentage Recovery (\%R) for the Heavy Metals}

Table 1 shows the values for FAAS measuring conditions and percentage recovery $(\% \mathrm{R})$ for the heavy metals. Regression values $\left(\mathrm{r}^{2}\right)$ ranged between 0.9593 and 0.9909 while the recoveries of heavy metals ranged from $85.56 \%$ in $\mathrm{Cd}$ to $93.66 \%$ in $\mathrm{Zn}$. Under the experimental conditions used, the standard calibration curves having $\mathrm{r}^{2}$ of not less than 0.9593 showed high linearity level and the $\% \mathrm{R}$ was $\geq 85.56 \%$. Also, the percentage relative standard deviation (\%RSD) values of between 2.98 and $5.29 \%$ obtained for the heavy metals concentrations in the brain tissues showed that precision was better than 10\% RSD level. Hence, the performance of the instrument and the analytical procedures adopted were reliable and the values obtained were adjudged acceptable.

Table 1. Table showing FAAS regression curve $\left(\mathrm{r}^{2}\right)$ and percentage recovery $(\% \mathrm{R})$ for heavy metals in the tissue samples

\begin{tabular}{|c|c|c|}
\hline Heavy metal & Calibration curve, $\mathrm{r}^{2}$ & Percentage recovery $(\% \mathrm{R})^{\#}$ \\
\hline $\mathrm{Cd}$ & 0.9593 & $85.56 \pm 5.29$ \\
\hline $\mathrm{Cu}$ & 0.9697 & $91.27 \pm 2.98$ \\
\hline $\mathrm{Pb}$ & 0.9824 & $89.86 \pm 5.01$ \\
\hline $\mathrm{Zn}$ & 0.9909 & $93.66 \pm 3.24$ \\
\hline
\end{tabular}

${ }^{\#}$ Values are mean of triplicate analysis $\pm \%$ RSD

\subsection{Levels of Heavy Metals in the Brain Tissue}

The levels of heavy metals in the brain tissues of rats are shown in Table 2. The mean metal levels ranged between $0.42 \mu \mathrm{g} / \mathrm{g} \mathrm{Cd}$ and $42.45 \mu \mathrm{g} / \mathrm{g} \mathrm{Zn}$ in the younger rats while the range was from $0.26 \mu \mathrm{g} / \mathrm{g} \mathrm{Cd}$ to $47.19 \mu \mathrm{g} / \mathrm{g} \mathrm{Zn}$ in the older rats. Total metal in the brain tissues of younger rats (Table 2) ranged from $49.87 \mu \mathrm{g} / \mathrm{g}$ to $82.93 \mu \mathrm{g} / \mathrm{g}$, while the range was between $50.74 \mu \mathrm{g} / \mathrm{g}$ and $105.64 \mu \mathrm{g} / \mathrm{g}$ in the older rats. From Figure 3, percentage essential metals (\%EM) in the brain tissues of group A (control group) was 98.78, while it was 97.65 and 98.23 in B and C (experimental groups), respectively. Also, in group D brain tissues (control group), the \%EM was 99.50 , whereas it was 98.58 and 98.75 in the brain tissues of $\mathrm{E}$ and $\mathrm{F}$, respectively (experimental groups). 
Table 2. Mean levels* of heavy metals $(\mu \mathrm{g} / \mathrm{g})$ in the brain tissue

\begin{tabular}{ccccc}
\hline Animal & \multicolumn{4}{c}{ Heavy Metals } \\
\hline Groups & $\mathrm{Zn}$ & $\mathrm{Cu}$ & $\mathrm{Cd}$ & $\mathrm{Pb}$ \\
\hline $\mathrm{A}$ & $\mathbf{5 8 . 5 0} \pm \mathbf{4 . 6 5}$ & $\mathbf{2 3 . 4 3} \pm \mathbf{1 . 4 3}$ & $\mathbf{0 . 3 6} \pm \mathbf{0 . 1 1}$ & $\mathbf{0 . 6 4} \pm \mathbf{0 . 1 3}$ \\
$\mathrm{B}$ & $31.03 \pm 1.45$ & $17.67 \pm 3.92$ & $0.50 \pm 0.08$ & $0.67 \pm 0.27$ \\
$\mathrm{C}$ & $37.83 \pm 9.86$ & $23.39 \pm 8.36$ & $0.39 \pm 0.08$ & $0.71 \pm 0.05$ \\
Mean \pm s.d. & $\mathbf{4 2 . 4 5} \pm \mathbf{1 4 . 3 1}$ & $\mathbf{2 1 . 5 0} \pm \mathbf{3 . 3 1}$ & $\mathbf{0 . 4 2} \pm \mathbf{0 . 0 7}$ & $\mathbf{0 . 6 7} \pm \mathbf{0 . 0 4}$ \\
$\mathrm{D}$ & $\mathbf{7 3 . 2 3} \pm \mathbf{3 . 5 2}$ & $\mathbf{3 1 . 8 8} \pm \mathbf{2 . 8 1}$ & $\mathbf{0 . 2 2} \pm \mathbf{0 . 0 3}$ & $\mathbf{0 . 3 1} \pm \mathbf{0 . 0 3}$ \\
E & $33.61 \pm 9.51$ & $16.41 \pm 5.78$ & $0.23 \pm 0.07$ & $0.49 \pm 0.11$ \\
F & $34.73 \pm 5.86$ & $32.56 \pm 3.41$ & $0.34 \pm 0.20$ & $0.51 \pm 0.20$ \\
Mean \pm s.d. & $\mathbf{4 7 . 1 9} \pm \mathbf{2 2 . 5 6}$ & $\mathbf{2 6 . 9 5} \pm \mathbf{9 . 1 3}$ & $\mathbf{0 . 2 6} \pm \mathbf{0 . 0 7}$ & $\mathbf{0 . 4 4} \pm \mathbf{0 . 1 1}$ \\
\hline
\end{tabular}

$*$ Value $=$ mean of triplicate determinations \pm s.d.

\subsection{Cerebral Histology and Architecture}

The photomicrographs of the molecular $(\mathrm{M})$, external granular $(\mathrm{G})$, external pyramidal $(\mathrm{P})$, internal granular (IG) and internal pyramidal (IP) layers of the cerebral cortex of groups A, B and C rats are shown in Fig. 1. Morphologically normal glial cells were noted in the molecular layers of the control and experimental groups. Features of early neuronal necrosis were noted in the internal granular layer (IG) of the experimental rat groups. Neurons with central chromatolysis (yellow arrow) were noted in layers G, IG and IP while those with basophilic necrosis (red arrow) were noted in layers G, P, IG and IP of the experimental groups. Pyknotic glial cells (brown arrow) were noted in layers G, P, IG and IP of group C micrograph.

Fig. 2 shows the photomicrographs of the molecular (M), external granular $(\mathrm{G})$, external pyramidal $(\mathrm{P})$, internal granular (IG) and internal pyramidal (IP) layers of the cerebral cortex of groups D, E and F rats. Essentially normal glial cells were noted in the molecular layers $(\mathrm{M})$ of the experimental and control rat micrographs. Basophilic necrotic neurons were noted in layers G, P, IG and IP of the experimental group rats, while neurons with central chromatolysis were noted in layers $\mathrm{P}$ and IG of the group E rats. Early neuronal necrosis were noted in layers IG and IP of the 2 experimental groups as well as layer $\mathrm{G}$ of group $\mathrm{F}$ rat. Glial cell pyknosis was noted in layers $\mathrm{P}$ and IG of group $\mathrm{F}$ rat. In addition to the above, cortical layers of each group contain some morphologically normal cells. 


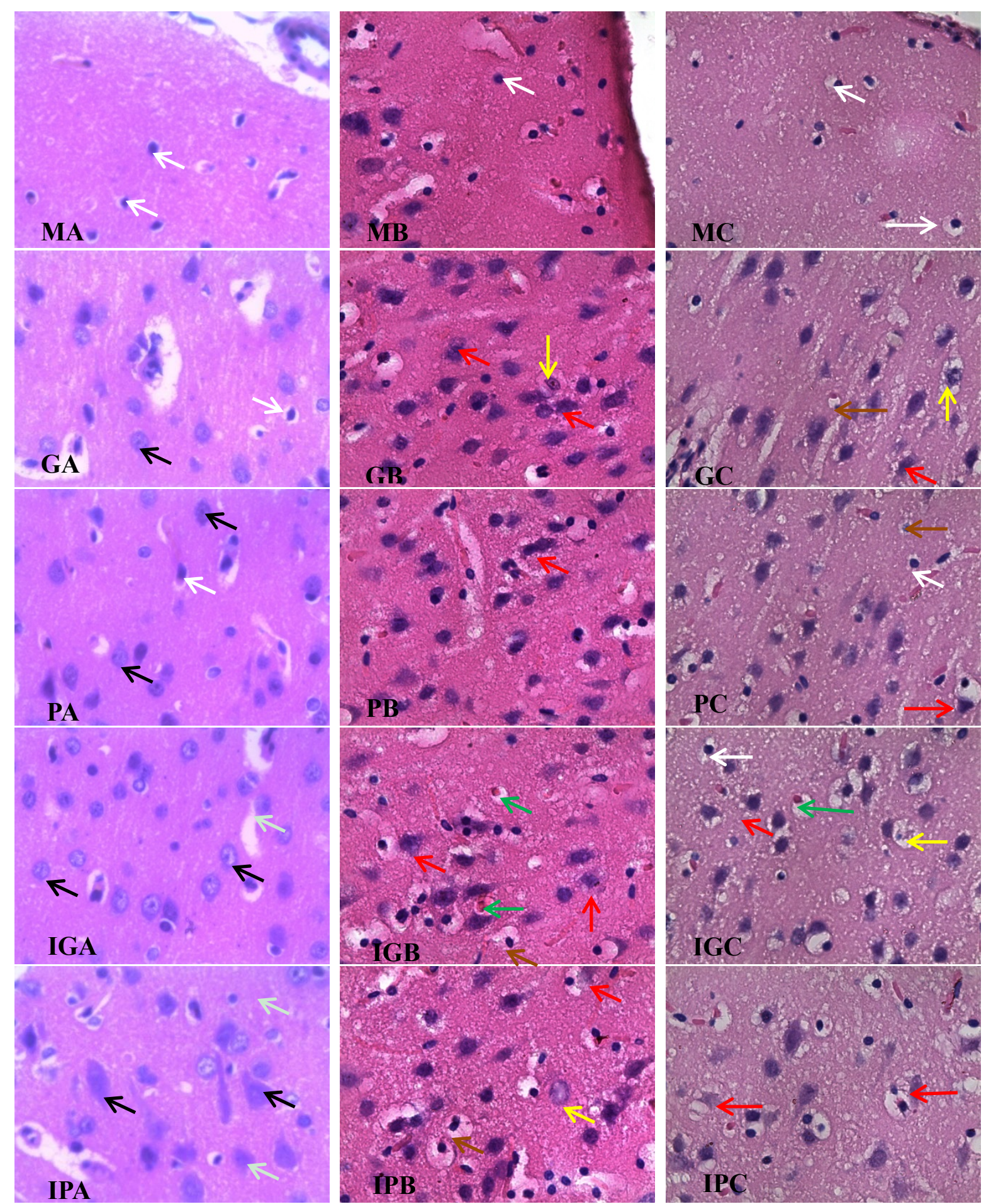

Figure 1. Photomicrographs of the molecular $(\mathrm{M})$, external granular $(\mathrm{G})$, external pyramidal $(\mathrm{P})$, internal granular (IG) and internal pyramidal (IP) layers of groups A, B and C. Neurons with central chromatolysis (yellow arrow), Basophilic necrotic neuron (Red arrow), early neuronal necrosis (Green arrow), normal oligodendrocyte (White arrow), normal neurons (Black arrow) and pyknotic glial cell (Brown arrow). Stain H\&E. Mag. X400 


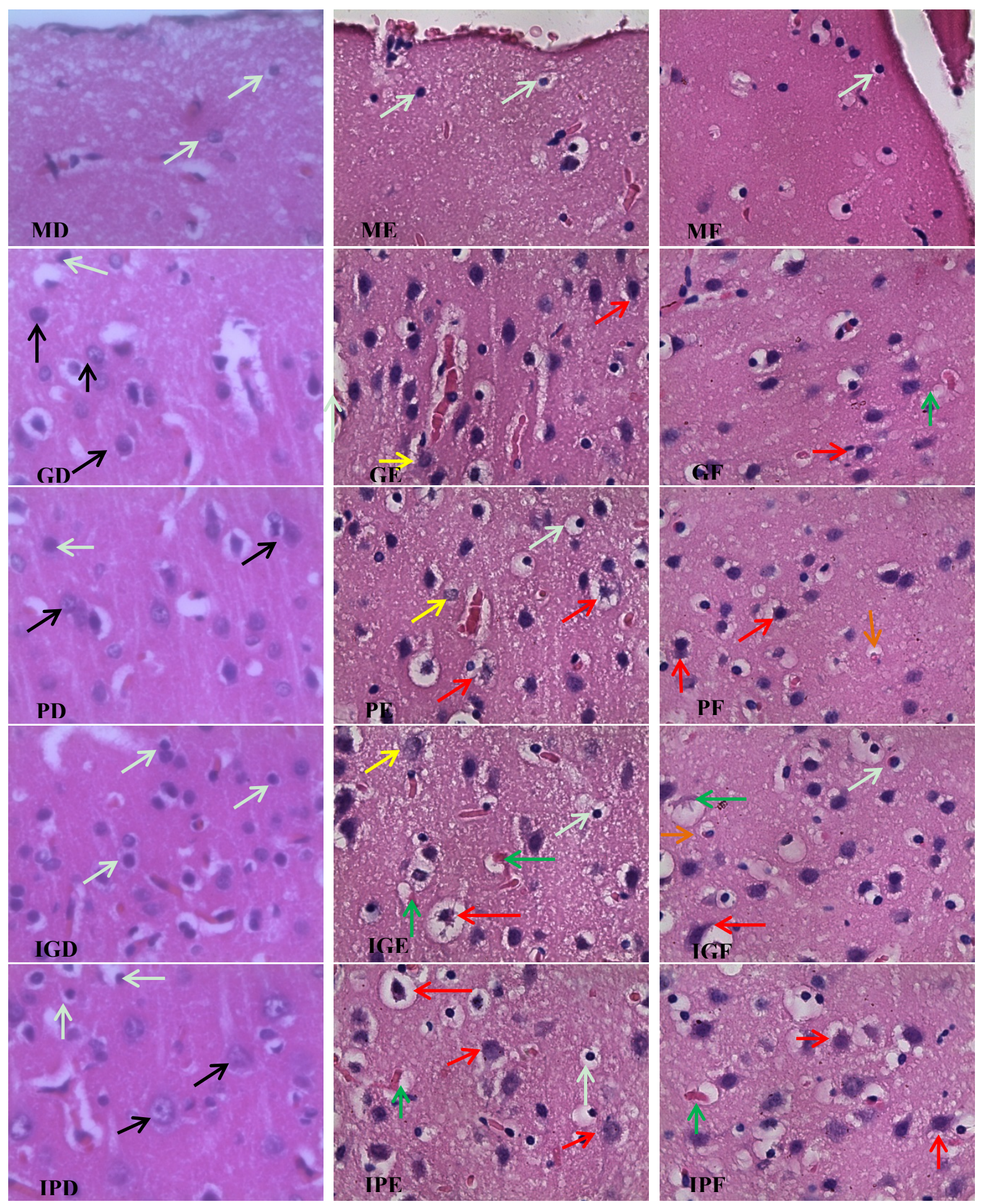

Figure 2. Photomicrographs of the molecular (M), external granular (G), external pyramidal (P), internal granular (IG) and internal pyramidal (IP) layers of groups D, E and F. Neurons with central chromatolysis (yellow arrow), Basophilic necrotic neuron (Red arrow), early neuronal necrosis (Green arrow), normal oligodendrocyte (White arrow), normal neurons (Black arrow) and pyknotic glial cell (Brown arrow). Stain H\&E. Mag. X400 


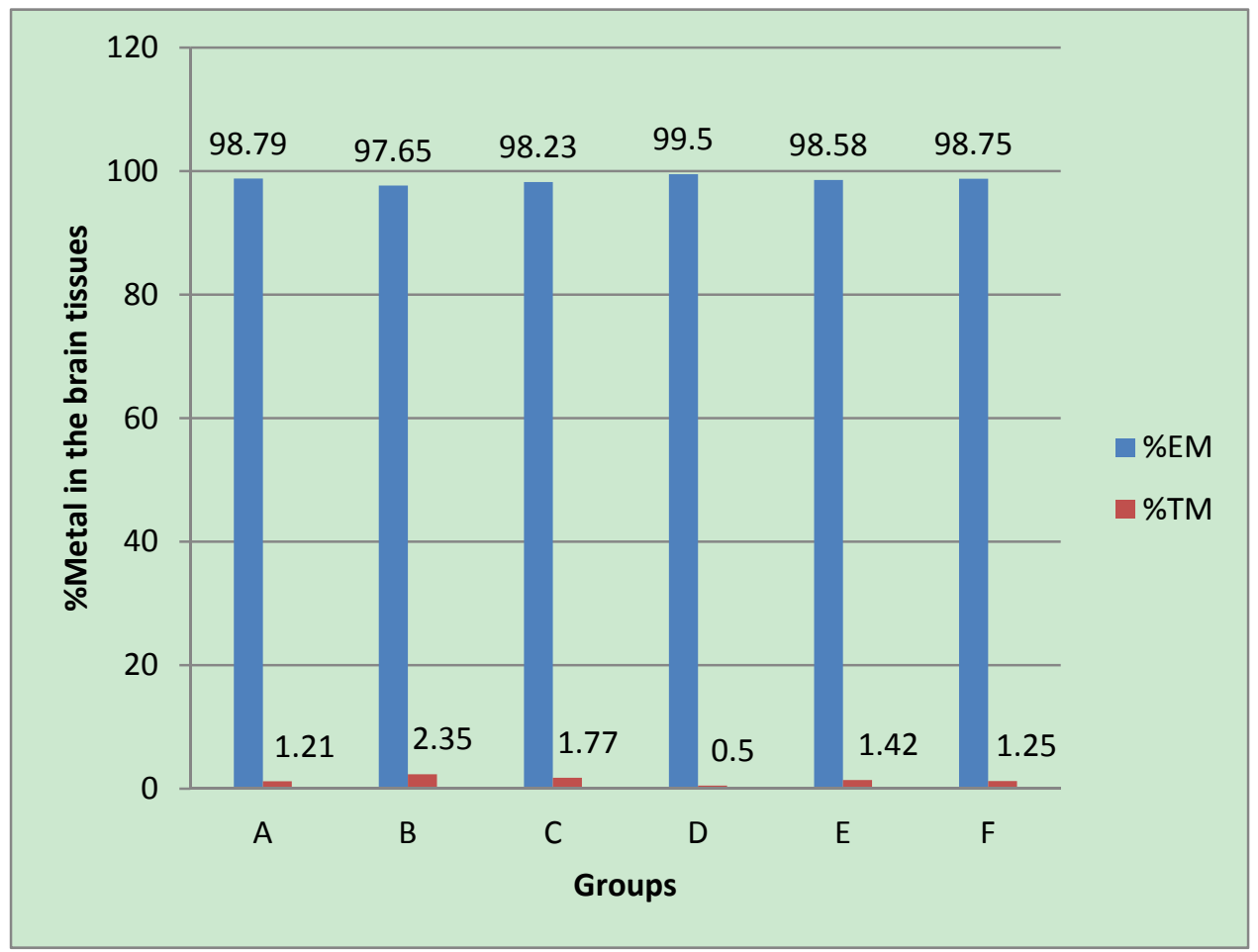

Figure 3. Percentages of essential metals (\%EM) and toxic metals (\%TM) in brain tissues of rats

\section{Discussion}

Copper, Zinc, Lead and Cadmium were detected in the brain tissues of both the control and experimental rat groups to an appreciable levels implying that the brain tissues actually contained background levels that could have come through the parents of the rats or from their feeds. Apparently, the younger rats appeared to be able to accommodate more Cadmium and Lead in their brain tissues more than the older rats. This might be as a result of more active biochemical and metabolic processes associated with the growth stage of younger animals. In both younger and older rat groups, the levels of $\mathrm{Cu}$ and $\mathrm{Zn}$ detected in the brain tissues were significantly higher than the levels of $\mathrm{Cd}$ and $\mathrm{Pb}$. This could be because essential metals such as $\mathrm{Cu}$ and $\mathrm{Zn}$ are useful for metabolic maintenance of cells and organs whereas toxic metals such as $\mathrm{Cd}$ and Pb are not (IPCS, 2005-2007). When the levels of metals in the brain tissues of the experimental rats are compared with those of the control groups, it was noted that the levels of $\mathrm{Cu}$ and $\mathrm{Zn}$ (trace elements) were reduced drastically in the experimental groups, while conversely, $\mathrm{Cd}$ and $\mathrm{Pb}$ levels increased appreciably. These changes were possibly due to more $\mathrm{Cd}$ and $\mathrm{Pb}$ availability to substitute $\mathrm{Zn}$ and $\mathrm{Cu}$ in their metabolic functions in the rat brain tissues. This fact is further strengthened by Figure 3 where the \%EM in the brain tissues fell from 98.79 in group A (control group) to 97.65 and 98.23 , respectively in groups B and C (experimental groups). Similarly, in the older groups, the levels of essential metals decreased from $99.50 \%$ in group D (control group) to 98.58 and $98.75 \%$ in groups $\mathrm{E}$ and $\mathrm{F}$, respectively. The decrease in $\mathrm{Cu}$ and $\mathrm{Zn}$ brought about by $\mathrm{Cd}$ and $\mathrm{Pb}$ in the brain tissues might look marginal in some of the cases, the effects on the morphological modifications could be phenomenal, as could be seen in this study.

The exposure of rats to different concentrations of lead $(\mathrm{Pb})$ and cadmium $(\mathrm{Cd})$ was modulated by the concomitant administration of Copper $(\mathrm{Cu})$ and $\mathrm{Zinc}(\mathrm{Zn})$ on the cellular composition of the cerebrum. The distribution of glial cell pyknosis showed a direct relationship with concentration of the heavy metals. The presence of normal glial cell in all the layers of the cerebrum in the younger rats with lower dose of the heavy metal as against pyknosis of the same cells in most layers of the cerebrum of rats with higher dose of the heavy metal showed that the concentration of the heavy metal to which the brain is exposed determines its morphological effect on the glial cells. In addition, while the co-administration of $\mathrm{Cu}$ and $\mathrm{Zn}$ might be protective of the cortical glial cells, such protective capacity appeared to be dependent on the concentration of the heavy metals. A similar pattern was noted in the older rats. However, a more extensive glial cell pyknosis was noted in the younger rats compared with the older rats. This points to the possible modulating role of age on the capacity 
of the glial cells to withstand the neurotoxic effects of lead and cadmium. The glial cells of the molecular layer of the cerebrum (predominantly oligodendrocytes) were apparently protected in the 2 age groups and in the 2 heavy metal concentration sets. Whether or not the proximity of the cortical layer to the lateral ventricle has a role to play in heavy metal toxicity of cortical cells is a basis for further research. Hypoxic-ischemic brain injury is known to exacerbate cellular injury (Funk et. al., 2010; Droblenkov et. al., 2013). A direct link between heavy metal toxicity and vascular dysfunction does not fall within the scope of this study. However, such understanding might further shed light on the mechanism of glial cell morphological anomaly sequel to heavy metal toxicity. In the light of the observed anomaly of glial cell following exposure to $\mathrm{Pb}$ and $\mathrm{Cd}$, functions such as myelin sheath production, maintenance of the blood brain barrier and scavenging of cellular debris may be affected by heavy metal toxicity despite co-administration of essential elements such as copper and zinc.

Apart from the anomalies of the glial cells, varieties of neuronal anomalies were also associated with the heavy metal toxicity. While central neuronal chromatolysis was noted in various layers of the cerebrum in both heavy metal concentration groups in the young adult rats, this neuronal anomaly was noted in the external pyramidal and internal granular layers of the $5 \mathrm{ppm}$ subset of the older rat group. It appeared that the age of the rats has a modulatory role on the possible neurotoxic effects of lead and cadmium co-administered with copper and zinc. While vacuolated and pyknotic neurons were known to be associated with lead toxicity (Chander et al., 2014), the combined ingestion of cadmium and lead resulted in more diverse morphological anomalies of cortical neurons. Features of early neuronal necrosis was restricted to the internal granular layer in the younger rats, a more extensive picture was noted in the internal granular and internal pyramidal layers of the older rats. Neurons with basophilic necrotic pattern appeared to be a widespread morphological anomaly of the neurons in both ages and heavy metal concentration groups. Despite the co-administration of copper and zinc, the combined toxicity of lead and cadmium appear to have more extensive morphological effects on the neurons compared with the glial cells. This is in contrast to the generally held view that oligodendrocytes are more vulnerable in cortical cellular toxicity (Bradl \& Lassmann, 2010).

Co-administration of 5 to $10 \mathrm{ppm}$ of copper and zinc in heavy metal toxicity did not confer protection on the glial cells and neurons of the rat cortex. However, there appears to be a modulating role of rat's age on the extent and pattern of cellular degeneration in heavy metal toxicity. In addition, cortical neurons are more susceptible to the toxic effects of lead and cadmium despite co-administration of essential elements such as copper and zinc compared with the glial cells.

\section{References}

Alloway, B. J., \& Jackson, A. P. (1991, March). The behavior of heavy metals in sewage sludge-amended soils. Sci. Total Environ., 100 Spec No, 151-176. http://dx.doi.org/10.1016/0048-9697(91)90377-Q

Baykov, B., Gugova, M., Stoyanov, M., Neychev, H., Stefanova, T., \& Nicolova, N. (1996, December). Designing an artificial ecological mesocosm for the study of $\mathrm{Cd}$ and $\mathrm{Pb}$ impact on the immune system of experimental animals. Toxicol Lett., 89(1), 5-10. http://dx.doi.org/10.1016/S0378-4274(96)03775-7

Bernard, A. (2004, October). Renal dysfunction induced by cadmium: biomarkers of critical effects. Biometals., 17(5), 519-523. http://dx.doi.org/10.1023/B:BIOM.0000045731.75602.b9

Bradl, M., \& Lassmann, H. (2010, January). Oligodendrocytes: biology and pathology. Acta Neuropathol., 119(1), 37-53. http://dx.doi.org/10.1007/s00401-009-0601-5

Bulat, Z. P., Dukic-Cosic, D., Dokic, M., Bulat, P., \& Matovic, V. (2009, March). Blood and urine cadmium and bioelements profile in nickel-cadmium battery workers in Serbia. Toxicol Ind Health., 25(2), 129-135. http://dx.doi.org/10.1177/0748233709104488

Chander, K., Vaibhav, K., Ejaz Ahmed, M., Javed, H., Tabassum, R., Khan, A., ... Siddiqui, M. S. (2014, Junuary). Quercetin mitigates lead acetate-induced behavioral and histological alterations via suppression of oxidative stress, Hsp-70, Bak and upregulation of Bcl-2. Food Chem Toxicol., 68, 297-306. http://dx.doi.org/10.1016/j.fct.2014.02.012

Cunningham, R. D. Jr. (1995, February 8). Childhood lead poisoning in 1994. JAMA., 273(6), 458. http://dx.doi.org/10.1001/jama.1995.03520300028023

Droblenkov, A. V., Naumov, N. V., Monid, M. V., Valkovich, E. I., \& Shabanov, P. D. (2013). Reactive changes of the rat brain cellular elements under different conditions of circulatory hypoxia. Morfologiia., 143(3), $14-21$.

Fox, M. R. (1979, April). Nutritional influences on metal toxicity: cadmium as a model toxic element. Environ 
Health Perspect., 29, 95-104. http://dx.doi.org/10.1289/ehp.792995

Fullmer, C. S. (1992, Winter). Intestinal interactions of lead and calcium. Neurotoxicology, 13(4), 799-807.

Garry, P. J. (2001, August). Aging successfully: a genetic perspective. Nutr Rev., 59(8 Pt 2), S93-101. http://dx.doi.org/10.1111/j.1753-4887.2001.tb05508.x

Goyer, R. A. (1996, October). Results of lead research: prenatal exposure and neurological consequences. Environ Health Perspect., 104(10), 1050-1054. http://dx.doi.org/10.1289/ehp.961041050

Grandjean, P., \& Nielsen, T. (1979). Organolead compounds: environmental health aspects. Residue Rev., 72, 97-148. http://dx.doi.org/10.1007/978-1-4612-6214-5_4

Horký, D., Illek, J., \& Pechová, A. (2002, March 15). Histochemical and ultrahistochemical localization of heavy metals in calf organs. Microsc Res Tech., 56(6), 435-450. http://dx.doi.org/10.1002/jemt.10043

IPCS. (2005-2007). Cadmium, cadmium chloride, cadmium oxide, cadmium sulphide, cadmium acetate, cadmium sulphate. Geneva, World Health Organization, International Programme on Chemical Safety (International Chemical Safety Cards 0020, 0116, 0117, 0404, 1075 and 1318; http://www.who.int/ipcs/publications/icsc/en/index.html).

Jurczuk, M., Moniuszko-Jakoniuk, J., Brzóska, M. M., Roszczenko, A., \& Vitamins, E. (2005). Concentrations in the Liver and Kidney of Rats Exposed to Cadmium and Ethanol. Pol. J. Environ. Stud., 14(5), 599.

Kjellström, T. (1992). Mechanism and epidemiology of bone effects of cadmium. IARC Sci Publ., (118), 301-310.

Lanphear, B. P., Hornung, R., Ho, M., Howard, C. R., Eberly, S., \& Knauf, K. (2002). Environmental lead exposure during early childhood. J Pediatr., 140(1), 40-47. http://dx.doi.org/10.1067/mpd.2002.120513

Lopez-Alonso, M., Benedito, J. L., Miranda, M., Castillo, C., Hernandez, J., \& Shore, R. F. (2002, July). Cattle as biomonitors of soil arsenic, copper and zinc concentrations in Galicia (NW Spain). Arch Environ Contam Toxicol., 43(1), 103-108. http://dx.doi.org/10.1007/s00244-002-1168-5

Louekari, K., Uusitalo, U., \& Pietinen, P. (1989, August). Variation and modifying factors of the exposure to lead and cadmium based on an epidemiological study. Sci Total Environ., 84, 1-12. http://dx.doi.org/10.1016/0048-9697(89)90365-3

Needleman, H. L. (1987, October). Biomarkers in neurodevelopmental toxicology. Environ Health Perspect., 74, 149-152. http://dx.doi.org/10.1289/ehp.8774149

Nordberg, G. F., Goyer, R. A., \& Clarkson, T. W. (1985, November). Impact of effects of acid precipitation on toxicity of metals. Environ. Health Perspect, 63, 169-180. http://dx.doi.org/10.1289/ehp.8563169

Nriagu, J. O., \& Sprague, J. B. (1987). Effects of Cadmium on Freshwater Fish from Cadmium in the Aquatic Environment. John Wiley and Sons, New York, NY, pp. 139-169.

Ogunfowokan, A. O., Famuyiwa, S. O., Adenuga, A. A., \& Fatoki, O. S. (2002, Sepember). Determination of cadmium and lead in urine of some Nigerian subjects. Int $J$ Environ Health Res., 12(3), 283-287. http://dx.doi.org/10.1080/0960312021000001041

Orisakwe, O. E. (2014, February). Lead and cadmium in public health in Nigeria: physicians neglect and pitfall in patient management. North American Journal of Medical Science, 6(2), 61-70. http://dx.doi.org/10.4103/1947-2714.127740

Phillips, C., Gyori, Z., \& Kovács, B. (2003). The effect of adding cadmium and lead alone or in combination to the diet of pigs on their growth, carcase composition and reproduction. Journal of the Science of Food and Agriculture, 83(13), 1357-1365. http://dx.doi.org/10.1002/jsfa.1548

Pier, S. M. (1975). The role of heavy metals in human health. Tex Rep Biol Med., 33(1), 85-106.

Schantz, S. L., \& Widholm, J. J. (2001, December). Cognitive effects of endocrine-disrupting chemicals in animals. Environ Health Perspect, 109(12), 1197-1206. http://dx.doi.org/10.1289/ehp.011091197

Suresh, A., Sivaramakrishna, B., \& Radhakrishnaiah, K. (1993, December). Effect of lethal and sublethal concentrations of cadmium on energetics in the gills of fry and fingerlings of Cyprinus carpio. Bull Environ Contam Toxicol., 51(6), 920-926. http://dx.doi.org/10.1007/BF00198291

Suresh, B., Taraschewski, H., \& Jackwerth, E. (1994). Comparative Study of LeadAccumulation in Different Organs of Perch (Percafluviatilis) and Its Intestinal Parasite Acanthocephalus lucii. Bulletin of Environmental 
Contamination and Toxicology, 52, 269-273.

Triger, D. R., Crowe, W., Ellis, M. J., Herbert, J. P., McDonnell, C. E., \& Argent, B. B. (1989, January). Trace element levels in the blood of workers in two steel works and a non-ferrous plant handling lead and cadmium compared with a non-exposed population. Sci. Total Environ., 78, $241-261$. http://dx.doi.org/10.1016/0048-9697(89)90037-5

Wu, T., Buck, G. M., \& Mendola, P. (2003, May). Blood lead levels and sexual maturation in U.S. girls: the Third National Health and Nutrition Examination Survey, 1988-1994. Environ Health Perspect, 111(5), 737-741. http://dx.doi.org/10.1289/ehp.6008

\section{Copyrights}

Copyright for this article is retained by the author(s), with first publication rights granted to the journal.

This is an open-access article distributed under the terms and conditions of the Creative Commons Attribution license (http://creativecommons.org/licenses/by/3.0/). 